\title{
頸部郭清術後の副神経障害とリハビリテーション
}

\author{
鬼 塚 哲 郎
}

要旨 : 頸部郭清術後のリハビリテーションの目的は, 肩関節可動域の維持と肩周囲の関節痛, 筋肉痛の予防で ある。肩関節可動域訓練の要点は, なるべく早期に開始し, 最初は上肢の重力負荷が軽減されるような仰臥位 で開始すると安全である。過負荷による関節痛や筋肉痛を生じないように留意する。近年多く行われている副 神経を保存した頸部郭清術においても高率に副神経障害をきたしているためリハビリテーションが必要であ る。副神経を切除した頸部郭清術においても, リハビリテーションにより日常生活に支障のない上肢可動域が 得られるようになる。

キーワード : 頸部郭清術, 副神経, リハビリテーション

\section{Summary Spinal accessory nerve dysfunction and rehabilitation after neck dissections:}

Tetsuro Onitsuka. Division of Head and Neck Surgery, Shizuoka Cancer Center

The purposes of rehabilitation after neck dissection are to maintain the range of motion of the shoulder and prevent muscular pain and arthralgia in it. It is important that shoulder exercise to improve the range of motion is initiated soon after neck dissection and it is initially performed in a supine position to reduce the weight of the arm. It is also important not to produce muscular pain and arthralgia due to overexercise. Even in functional neck dissection, which has often been performed recently, this rehabilitation is necessary because of the high incidence of surgical damage to the accessory nerve. In neck dissection in which the accessory nerve has been removed surgically, a good range of motion of the shoulder without associated difficulties in daily life can be achieved by rehabilitation.

Key words: neck dissection, spinal accessory nerve, rehabilitation

[Received May 18, 2016, Accepted Oct. 3, 2016]

\section{はじめに}

頸部郭清術では副神経を切除する場合と保存でき る場合がある。しかし副神経を保存した頸部郭清術 においても術中に副神経を粗雑に扱えば副神経障害 をきたす。副神経を保存した頸部郭清術の僧帽筋の 脱神経率は $49 \sim 100 \%{ }^{1-5)}$ と報告されている。副神 経障害では僧帽筋麻痺のために肩周囲関節運動に障 害をきたす。肩周囲関節は 5 つの関節からなり複雑 繊細である。そのため僧帽筋麻痺によって自力で肩 周囲関節を十分に動かさない，または代償筋による

静岡県立静岡がんセンター頭頸部外科

[平成 28 年 5 月 18 日受付, 平成 28 年 10 月 3 日受理]
無理な運動を行っていると, 速やかに他動でも肩関 節可動域制限や関節痛, 筋肉痛をきたす。そして痛 みが出るとさらに上肢を動かせなくなるという悪循 環に陥る可能性がある。これが放置されると長期に わたり後遺症に悩む患者が増加することになる。こ こでは頸部郭清術後の副神経麻痺の病態, リハビリ テーションの効果, 要点などについて述べる。

\section{副神経障害の病態}

\section{1. 上肢外転障害}

僧帽筋麻痺による上肢の外転運動が障害される。

2. 肩周囲関節の下垂

僧帽筋は肩甲骨を脊柱に引き止める作用がある。 よって僧帽筋麻疩をきたすと, その作用を失い, 肩 
甲骨は下垂し外側偏位をきたす。結果として肩周囲 関節が下方に偏移し肩が下がる。特に立位では上肢 の重力の影響で顕著となる。

3. 肩周囲関節の諸問題

肩周囲には上腕骨，肩甲骨，鎖骨，胸骨，胸郭か らなる複数の関節がある。上肢運動では，これらの すべての関節がよどみなく機能することが必要であ り，複雑繊細といえる。これらの一つの関節に痛み が生じるだけで円滑な上肢機能が妨げられる。僧帽 筋麻瘏をきたすと，肩周囲関節が下垂し歪んだ状態 となっている。このような関節がずれた状態で，や みくもに上肢運動をさせると, 肩周囲関節障害や代 償筋の痛みを誘発するので注意が必要である。一 方，仮に僧帽筋麻痺の状態で，上肢を動かさない状 態が持続すると，肩周囲関節が，間もなく癒着をは じめ, 関節可動域制限を生じてくる（癒着性関節包 炎)。すると副神経が保存された頸部郭清術後の一 過性の僧帽筋麻痺の回復後でも, 上肢運動障害を訴 えることになる。このような理由から, 頸部郭清術 後の僧帽筋麻瘏では, 肩周囲関節の偏移を補正しつ つ, 関節の癒着を防ぐような患者指導, リハビリ テーションが必要となる。

\section{リハビリテーションの要点}

\section{1. 肩周囲関節の可動域維持}

頸部郭清術後は, 僧帽筋麻瘏や痛みにより上肢運 動が制限されるが，これは前述のごとく，容易に複 数の肩周囲関節の癒着をきたす。この防止のために は, ドレーン抜去後の早期から, 肩関節可動域訓練 を行うことが望ましい。ベッドサイドにて医療者が 患者の上肢を持って外転や屈曲運動を行う。肩周囲 関節は下垂し歪んだ状態にあるため，より正常に近 い肩周囲関節の状態になるように留意しながら行 う。早期から適正なリハビリテーションの指導を行 わない限り, 多くの患者は, 創部痛や創へのマイナ ス影響を考え，頸部や上肢を動かさない。そのこと だけでも，上肢の可動域低下や肩周囲の凝りや痛み を誘発する。頸部郭清術のみの患者では 1 週間程度 で退院となるため，上肢を動かしても痛みが生じな いことを医療者と確認し安心させることが重要であ る。上肢を動かす怖さを取り除き, 自宅でのリハビ リテーションにつなげる効果がある。自宅でのリハ ビリテーションでは, 僧帽筋麻痺が重度の時には立 位や座位から開始すると上肢の重さが過負荷とな り，僧帽筋麻痺に伴う肩周囲関節の下垂を助長した り，大胸筋などの代償筋の過用による痛みを引き起 こす危険がある。上肢重力のかからない仰臥位での 自動運動から開始し, 僧帽筋の回復具合に応じて,
徐々に立位に変えていくとよい。当然ながら肩周 囲，上肢のリハビリテーションでは運動時痛が生じ ると上肢を動かせなくなるので，痛みの出るような 訓練は何らかの問題があるとして改善する必要があ る。リハビリテーションは患者の状況にそぐわなけ れば, 症状を悪化させる可能性もはらんでいる。訓 練強度や回数には注意を払い, 翌日に疲労や痛みが 残らない程度までとする。

2. 肩周囲の痛みの予防

僧帽筋麻痺の発症当初は, 肩周囲の痛みを誘発す るような日常生活動作や運動を避けるように指導す ることが重要である。二次的な痛みが生じると, 痛 みによって動かせなくなり, 関節可動域訓練も行え なくなるなど，悪循環に陥る。

痛みには, 関節痛, 筋肉痛がある。僧帽筋麻瘏が 生じている間は, 肩周囲関節が下垂し偏移している ため，関節痛をきたしやすい。また麻瘏した僧帽筋 を補う代償筋に過負荷がかかると, 代償筋の筋痛が 生じる。これを誘発するような日常生活動作は行わ ないように指導する。具体的には, 重い荷物を持た ない, 腕を下げない, 買い物かごを持たない, 子供 を抱かない, 自己判断での無理な運動（ラジオ体操 やダンベルを持った体操など）は行わないように指 導する。

患者指導用プリント（図 1)

これまで述べた要点を患者指導用のプリントで説 明し，自宅でのリハビリテーションを継続するよう に指導する。「仰向けになって行うこと」（図 1 プリ ント左上), リハビリテーションの要点は「肩の動 きを維持したり, 痛みを引き起こさないよう予防し ていくこと」(図 1 プリント右中段), 日常生活の注 意点と対策（図 1 プリント右下段）などが記載され ている ${ }^{6-8)}$ 。

\section{リハビリテーションの実際}

1. 副神経が切除された頸部郭清術後

副神経切除され再建がなされていない場合には, 副神経の回復が見込めず，僧帽筋の障害が永続す る。よって代償筋の強化により肩の外転・屈曲運動 を可能な範囲で改善していくことが必要なことを説 明する。副神経が保存された場合と同様に, 患者指 導用プリントなどを活用し, 肩甲帯の運動や肩関節 可動域訓練を行う。リハビリ専門のスタッフのいる 施設では，僧帽筋と同じ働きをする協働筋・代償筋 の筋力増強訓練として大小菱形筋, 前鋸筋などの運 動を指導することが望ましい。誤った方法（過度な 運動負荷）・姿勢での運動は, 逆にそれらの筋の痛 みなどを出現・増強させることにもなるため, 訓練 


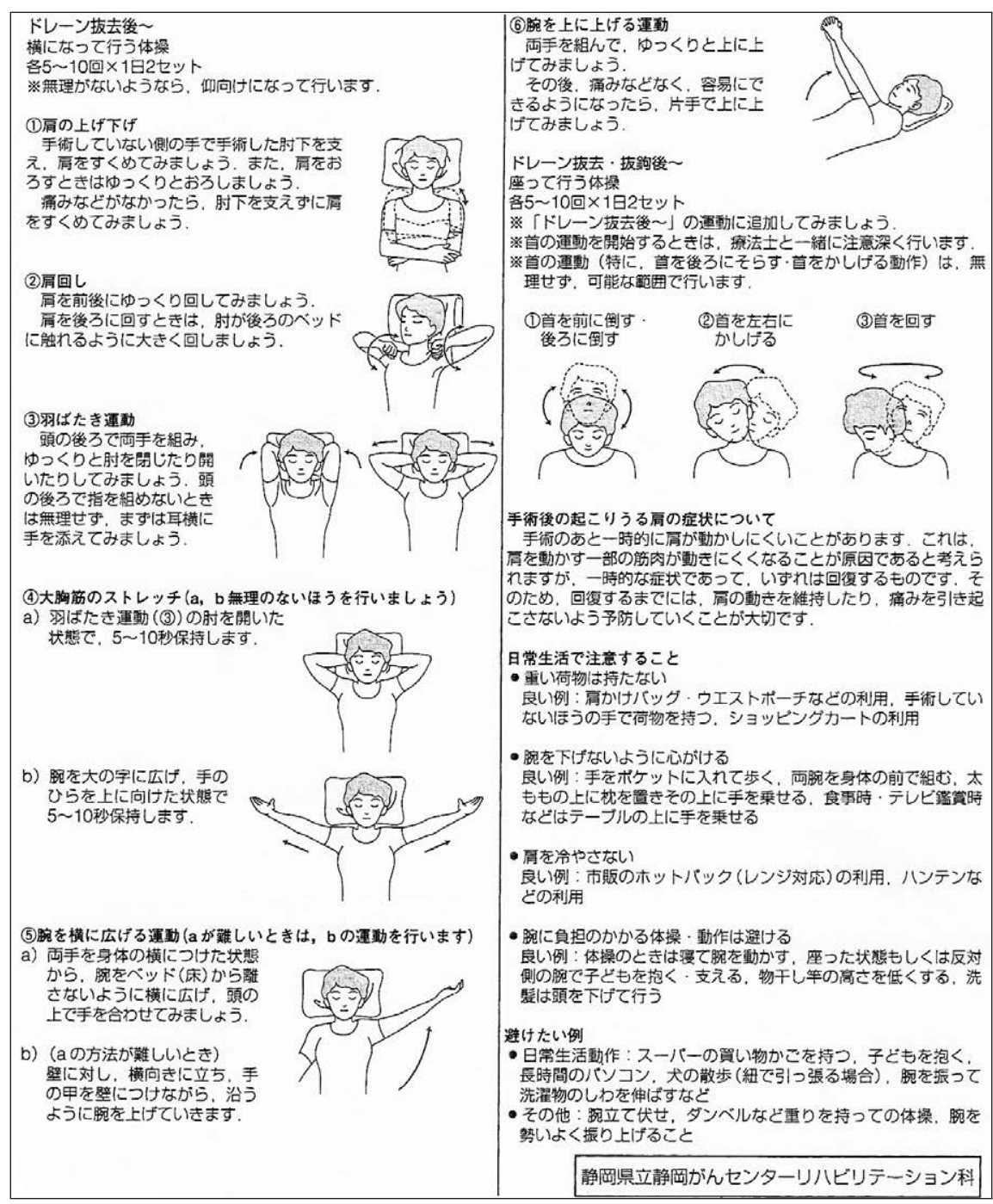

図 1 患者指導用プリント

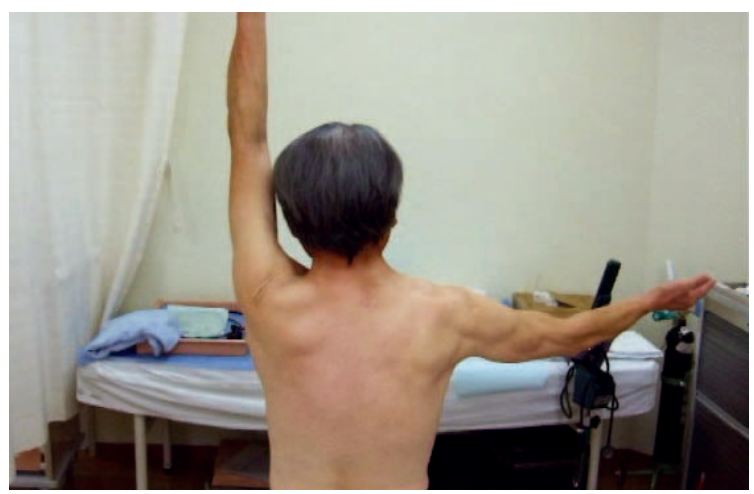

図 2 右根治的頸部郭清術（副神経切除）後 10 年。 リハビリなし。癒着性関節包炎により右上肢 は 90 度までしか外転できず, 肩周囲のこわ ばりや痛みも強く訴える。

時に適宜修正・指導していく。

図 2 は根治的頸部郭清術（副神経再建なし）を施 行され，リハビリテーションなしで 10 年経過した 症例である。癒着性関節包炎により右上肢は 90 度

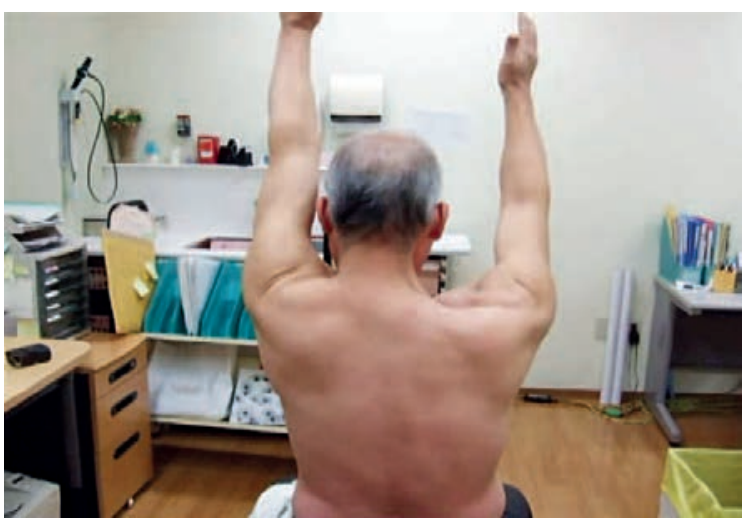

図 3 右根治的頸部郭清術（副神経切除）後 6 年。 リハビリあり。外転運動が可能である。

までしか外転できず, 肩周囲のこわばりや痛みの訴 えも強く，いわゆる shoulder syndrome を呈して いる。一方, 図 3 は術後早期からリハビリテーショ ンを行った症例である。肩関節可動域訓練により癒 着性関節包炎が予防されるとともに代償筋が強化さ 
れ，上肢外転運動が可能となっている。また注目す べきことは，肩周囲のこわばりや痛みの訴えがない ことである。Shimada ら ${ }^{9}$ は根治的頸部郭清術（副 神経再建なし）の患者の術後をリハビリテーション の有り無しで比較し, リハビリテーションによって 明らかに上肢機能が優れると報告している。

2. 副神経が保存された頸部郭清術後

副神経を保存した頸部郭清術においても, 術後は 高率に僧帽筋麻痺をきたしているが，多くは軸索障 害による一時的（通常は半年〜 1 年程度）なもので あり回復が期待できる ${ }^{10)}$ 。回復するまでの間, 関節 の拘縮（肩関節に関与する筋や関節が固くなるこ と）などの廃用症候群を予防し, 神経回復に備える こと, 回復までの間に過負荷とならないようなホー ムプログラム指導, 生活指導を行う。

3. リハビリテーション終了の目安

社会的背景, 仕事, 家事, 育児の必要性などの背 景を考慮して, 個々の社会生活に必要なレベルまで 回復が得られたら終了とする。具体的には, 専業主 婦，建築業，漁業などにより各々が重いものを運ぶ 作業などが可能となり, 疼痛・肩凝り・大胸筋など への過負荷などを生じていなければ終了とする。

著者は申告すべき利益相反を有しない。

\section{文献}

1) Tsuji $T$, Tanuma A, Onitsuka $T$, et al: Electromyographic findings after different selective neck dissections. Laryngoscope $117:$ 319-322, 2007.

2) Remmler D, Byers R, Scheetz J, et al: A prospective study of shoulder disability resulting from radical and modified neck dissections. Head Neck Surg $8:$ 280-286, 1986.

3) Patten C, Hillel AD: The 11th nerve syndrome. Accessory nerve palsy or adhesive capsulitis?. Arch Otolaryngol Head Neck Surg 119 : 215-220, 1993.

4) Köybasioglu A, Tokcaer AB, Uslu S, et al: Accessory nerve function after modified radical and lateral neck dissection. Laryngoscope $110: 73-77,2000$.

5) Salerno G, Cavaliere M, Foglia A, et al: The 11th nerve syndrome in functional neck dissection. Laryngoscope $112:$ 1299-1307, 2002.

6）鬼塚哲郎, 飯田善幸, 上條朋之, 他：当院における 頸部郭清術後のリハビリテーション。耳鼻と臨床, $55: 3-10,2009$

7）鬼塚哲郎, 田沼 明：耳鼻咽喉科領域の術後機能評 価, 頸部郭清術. 耳喉頭頸, 82 : 393-398, 2010.

8）田尻寿子, 鬼塚哲郎：身につけたいリハビリテー ションの最新スキル, 頸部リンパ節郭清後の上肢の 障害. 耳喉頭頸, 85 : 334-338, 2013.

9) Shimada $Y$, Chida S, Matsunaga $T$, et al: Clinical results of rehabilitation for accessory nerve palsy after radical neck dissection. Acta Otolaryngol 127 : 491-497, 2007

10）鬼塚哲郎, 海老原 充, 飯田善幸, 他 : 副神経を保 存した頸部郭清術における僧帽筋麻痺の経時的回復. 頭頸部癌, $34: 67-70,2008$. 